\title{
Characteristics of Radiological Description of TB-HIV Patients Based on CD4 Levels and Results of TCM Examination
}

\section{Iin Novita Nurhidayati Mahmuda*, Angiesta Pinakesty, Poetrie Wulandari Ruswandi, Nandya Herdiana and Triana Rahma Juwita}

Faculty of Medicine, Muhammadiyah University of Surakarta, Indonesia

*Corresponding Author: Iin Novita Nurhidayati Mahmuda, Faculty of Medicine, Muhammadiyah University of Surakarta, Indonesia.
Received: March 05, 2021

Published: April 27, 2021

(C) All rights are reserved by Iin Novita

Nurhidayati Mahmuda., et al.

\begin{abstract}
Tuberculosis (TB) is an opportunistic infection that is most often found in HIV infection and is the leading cause of death in PLWHA (people living with HIV/AIDS). The risk of TB transmission is 26 to 31 times greater in people with HIV than in people without HIV. There are obstacles in determining the diagnosis and management because HIV patients coinfected with TB usually have a negative smear test result and tend to have less characteristic radiological features. The number of clusters of differentiation 4 (CD4) and the results of the Rapid Molecular Test (TCM) are associated with clinical manifestations of HIV patients that can be seen from the radiological picture. This study aims to determine the characteristics of the radiological features of TB-HIV patients based on CD4 levels and TCM results. This research used a descriptive research design and was conducted from November to December 2020 at PKU Muhammadiyah Surakarta Hospital. The number of research subjects as many as 10 patients taken by purposive sampling technique. Retrieval of data using patient medical record data. The results of this study found that TB-HIV patients with very low CD4 cell counts and negative TCM results were the most common. The dominant radiological features found in this study are radiological features typical of TB. It can be concluded that very low CD4 cell counts and negative TCM results in TB-HIV patients tend to have the radiological features characteristic of TB. Retrieval of data using patient medical record data. The results of this study found that TB-HIV patients with very low CD4 cell counts and negative TCM results were the most common. The dominant radiological features found in this study are radiological features typical of TB. It can be concluded that very low CD4 cell counts and negative TCM results in TB-HIV patients tend to have the radiological features characteristic of TB. Retrieval of data using patient medical record data. The results of this study found that TB-HIV patients with very low CD4 cell counts and negative TCM results were the most common. The dominant radiological features found in this study are radiological features typical of TB. It can be concluded that very low CD4 cell counts and negative TCM results in TB-HIV patients tend to have the radiological features characteristic of TB.
\end{abstract}

Keywords: Tuberculosis; HIV; CD4; Molecular Rapid Test; Radiological Features

\section{Abbreviations}

Tuberculosis (TB) infection is still a world problem because it is in the first rank of death in infectious diseases caused by a single infectious agent. As many as $50 \%$ of the world's population have suffered from a disease that is most common at this productive age. Found 539,000 new TB cases with positive acid-resistant bacteria (BTA) test results with a mortality rate of 101,000 annually in Indonesia [1].

Tuberculosis is an opportunistic infection that is most often found (40\%) in HIV infection and is the leading cause of death 
among PLWHA (people living with HIV/AIDS). The incidence of TB-HIV co-infection is a serious case which, if not treated immediately, will cause problems that are difficult to control. The risk of TB transmission is 26 to 31 times greater in people with HIV than in people without HIV. A total of 9.6 million new TB cases were reported in 2014 and it is known that 1.2 million of them are people with HIV [2]. HIV can activate the bacterial infection Mycobacterium tuberculosis and the presence of opportunistic tuberculosis infection increases the progression of HIV [3].

The increase in TB co-infection cases in people living with HIV/ AIDS (PLWHA) could lead to an increase in new TB cases in healthy people or people without HIV/AIDS. In addition, this case also has its own constraints in determining the diagnosis and management because the clinical manifestations of HIV patients with lung disorders are often atypical. The sooner the diagnosis of TB-HIV sufferers, the more effective the therapy will be [4]. Based on a study conducted by Dafitri., et al. (2020) states that the diagnosis of pulmonary tuberculosis in people with HIV/AIDS is in principle the same as HIV negative people, including by means of a rapid molecular test (TCM), examination of sputum AFB (Acid-Resistant Bacteria), and radiological examinations [5].

TCM examination is needed to help diagnose pulmonary tuberculosis and detect the presence of Mycobacterium tuberculosis germs automatically with molecular examinations and at the same time detecting bacterial resistance to rifampin, so that the TCM examination can give better results on the sputum AFB examination [6]. Research conducted by Afriliyantina., et al. (2015) regarding the accuracy of TCM to diagnose TB HIV obtained a sensitivity of $93 \%$ and a specificity of $91.3 \%$ [7]. The TCM examination has the ability to detect bacteria up to $100-1000$ bacilli/ml of sputum. The TCM results are interpreted as positive if Mycobacterium tuberculosis or MDRTB (Multidrug-resistant tuberculosis) is detected and negative if no Mycobacterium tuberculosis is detected. Although the gold standard of testing for tuberculosis is culture, radiological examination is recommended in patients with a negative smear test because HIV coinfected patients with TB usually have a negative smear test result and tend to have less characteristic radiological features. This makes it more difficult for HIV coinfected TB patients to be diagnosed [8].
Jendriella., et al. (2019) stated that radiological and laboratory images can help diagnose TB-HIV patients. The number of clusters of differentiation 4 (CD4) has a close relationship with the clinical manifestations of HIV patients which can be seen from the radiological picture [4]. TB-HIV patients with CD4 counts> 200 cells/ $\mu \mathrm{L}$, can have radiological images that are still within normal limits, typical or there are cavities. TB-HIV patients with lower CD4 cell counts may present with lymphadenopathy and atypical radiological features [9].

However, until now there are not many studies that show radiological features of TB-HIV patients based on CD4 cell counts and TCM results. Therefore, based on the above background, the investigators were interested in examining the characteristics of the radiological features of TB-HIV patients based on CD4 cell counts and TCM test results.

\section{Methods}

This research was conducted in Surakarta in November-December 2020 using a descriptive research design. This research has received an ethical pass letter from KEPK FK UMS with numbers 3213/B.1/KEPK-FKUMS/I/2021 and 3249/B.1/KEPKFKUMS/I/2021.

The sampling technique used in this study was purposive sampling. The data collection technique is done by collecting secondary data. Secondary data were obtained from the medical records of TB-HIV patients at PKU Muhammadiyah Surakarta Hospital.

\section{Results and Discussion}

The study was conducted in November-December 2020 by taking secondary data in the form of medical records of TB-HIV patients at PKU Muhammadiyah Surakarta Hospital. Obtained 10 research samples that match the inclusion criteria and exclusion criteria of this study.

In this study, it was found that there were more male patients than female patients, namely 8 male patients (80\%) and 2 female patients $(20 \%)$. This is in line with research conducted by Hanifa 
(2019), which states that the highest percentage results for the sex category of TB-HIV sufferers at PKU Muhammadiyah Surakarta Hospital are men with a percentage of $67.86 \%$, while TB-HIV patients are female. by $32.14 \%[10]$.

\begin{tabular}{|c|c|c|}
\hline Variable & Amount & Percentage \\
\hline Gender & & \\
\hline Male & 8 & $80 \%$ \\
\hline Female & 3 & $20 \%$ \\
\hline Age (year) & & \\
\hline $19-40$ & 6 & $60 \%$ \\
\hline $41-60$ & 3 & $30 \%$ \\
\hline$>60$ & 1 & $10 \%$ \\
\hline
\end{tabular}

Table 1: Characteristics of research subjects.

This may be because men are more frequently exposed to TB risk factors, such as smoking habits and lack of medication adherence [11]. Cigarette smoke exposure can affect a person's immune level, so that it can affect the incidence of progression of TB germs becoming active. In addition, alcohol consumption also has a similar effect, which can weaken a person's immunity [12].

Based on age characteristics, TB-HIV patients in this study were predominantly affected by people aged 19 - 40 years, as many as 6 people (60\%). Then followed by the $41-60$ years age group as many as 3 people (30\%). The least age group $>60$ years was found as many as 1 person (10\%). These results are consistent with previous research conducted by Baedowi., et al. (2020) which states that TB-HIV sufferers at RSUD Dr. H Abdul Moeloek mostly occurred in the age group 31 - 40 years with a total of 92 people (47\%) [13]. Research conducted by Wesnawa and Putra (2016) also showed similar results that the most TB-HIV sufferers at Buleleng Hospital were the productive age group with an age range between $20-40$ years (80\%). This is in line with the fact that young adulthood is a time when there is a feeling of freedom, the courage to take risks, and increases the experience so that HIV infection among young people can start from experimenting, such as using drugs, consuming alcoholic beverages and unsafe sex, for example, having sex with multiple partners without using safety devices [14].

\begin{tabular}{|c|c|c|}
\hline Variable & Amount & Percentage \\
\hline CD4 $\left(\right.$ cell $\left./ \mathrm{mm}^{3}\right)$ & & \\
\hline Very Low $(<200)$ & 10 & $100 \%$ \\
\hline Low $(200-350)$ & 0 & $0 \%$ \\
\hline Normal $(>350)$ & 0 & $0 \%$ \\
\hline TCM & & \\
\hline Positive & 0 & $0 \%$ \\
\hline Negative & 10 & $100 \%$ \\
\hline Radiological Features & & \\
\hline Typical & 6 & $60 \%$ \\
\hline Atypical & 4 & $40 \%$ \\
\hline
\end{tabular}

Table 2: Subject frequency distribution based on CD4 Count, TCM, and radiological features.

This is in accordance with the research conducted by Muna and Cahyati (2019), which states that TB-HIV is more common in productive age (15 - 50 years), which is 26 (86.67\%), while in the nonproductive age group it is found as many 4 people (13,33\%) [15].

The highest proportion of CD 4 counts was $<200$ cells $/ \mathrm{mm}^{3}$ as many as 10 people, while there were no patients with CD4 counts of $200-350$ cells $/ \mathrm{mm}^{3}$ and $>350$ cells $/ \mathrm{mm}^{3}$. This study is similar to Widiyanti's (2015) study which divided two groups based on CD4 count, namely the group with CD $4<350$ cells $/ \mathrm{mm}^{3}$ and the group with CD4 $>350$ cells $/ \mathrm{mm}^{3}$. The study stated that patients with a CD4 count $<350$ cells $/ \mathrm{mm}^{3}$ were four times more likely to experience opportunistic infections than patients with a CD4 count $>350$ cells $/ \mathrm{mm}^{3}[16]$.

Based on the TCM results in this study, most TB-HIV patients had negative TCM results, amounting to 10 people (100\%). These results are in accordance with research conducted by Hanifa and Mahmuda (2019), regarding the results of TCM in HIV patients at PKU Muhammadiyah Surakarta Hospital, more than 11 were found with negative TCM results, amounting to 20 people $(71.43 \%)$ compared to positive TCM results. which only amounted to 8 people (28,57\%) [10]. Research by Kurniawan., et al. (2019) stated similar results from examining 40 samples of pulmonary TB patients at the 
Internal Medicine Inpatient Unit of Dr. M. Djamil and Puskesmas around the city of Padang obtained positive TCM results totaling 16 people $(40 \%)$ and negative TCM results totaling 24 people $(60 \%)$ [11]. This is related to the immune status of HIV patients who are at risk of being infected with non-tuberculosis microbacteria, thus affecting the TCM results. The molecular rapid test is only able to detect Mycobacterium tuberculosis, so further tests should be carried out for non-tuberculosis microbacteria such as liquid culture media. The non-tuberculosis microbacterial species most frequently isolated are Mycobacterium kansasii, Mycobacterium avium and Mycobacterium intracellulare. In addition, HIV patients are also often unable to excrete sputum of good quality and in sufficient quantities for bacteriological examination, so sputum collection can be done by sputum induction, broncoalveolar rinse (branchoalveolar lavage/BAL), and gastric aspiration [18]. Another factor that can affect the negative TCM results in HIV patients, namely the empiric TB treatment that has been given can reduce the viability of Mycobacterium tuberculosis so that it cannot be detected by TCM [19].

Based on the radiological picture, most of the TB-HIV sufferers had a typical feature of TB, which was 6 people $(60 \%)$, while the non-typical picture of TB was 4 people (40\%). This study is different from previous research conducted by Jendriella., et al. (2019) who showed that the radiological images in TB-HIV patients were more nonspecific than the radiological features typical of TB [4]. The possible causes of the radiological picture having a characteristic feature of TB in this study include the patient's immune system and body condition which is still quite good, so that even though he has been diagnosed with HIV positive, radiological examination will give a typical picture of TB. This is in accordance with the theory which states that patients with normal - mild immunosuppression, the results of radiological images are usually typical of TB, in the form of infiltrates in the upper field of the lung, cavities or unilateral pleural effusions, while patients with moderate to severe immunosuppression give radiological images that are not typical of TB. in the form of infiltrates in the mid and lower fields of the lung, form miliary or diffuse infiltrates and adenopathy [20]. Another factor that can affect the radiological picture of TBHIV patients is antiretroviral treatment (ARV) where patients who have received ARV treatment for the first two months often experience a paradoxical response where the patient suddenly feels tight but the CD4 (Cluster of Differentiation) increases sharply, thus providing a variety of radiological images, which can be miliary, pleural effusion and lymphadenopathy [21]. Nutritional status in HIV patients also affects the radiological picture, where the reduced body mass index (BMI) of a person, the wider the active pulmonary TB lesion on the radiological image, conversely, the higher the body mass index of a person, the less active pulmonary TB lesions on the radiological image [22].

Radiological examination is an important investigation in TBHIV patients. Chest x-rays are recommended for TB-HIV patients who cannot collect sputum despite sputum induction [5]. In addition, chest x-rays can also help diagnose opportunistic infections that occur in HIV patients. HIV patients with a severe degree of immunosuppression have a high risk of developing tuberculosis, but it is difficult to distinguish tuberculosis from other opportunistic infections. Classic symptoms of TB can appear in TB-HIV patients, but it is rare for patients with tuberculosis symptoms to be found, so radiological examination can help make the diagnosis [4].

Atypical radiological features are common in TB-HIV patients. The radiological picture is influenced by the degree of immunosuppression of TB-HIV patients [23]. In TB-HIV patients with mild immunosuppression, chest X-rays show a characteristic feature of TB, namely the presence of infiltrates in the apex of the lung and cavity. In TB-HIV patients with severe immunosuppression, chest X-rays show an atypical picture, namely the presence of diffuse infiltrates, especially in the middle and lower lobes without any cavities [24].

\section{Conclusions and Suggestions}

Based on the results of this study, it can be concluded that CD4 counts and negative TCM test results in TB-HIV patients tend to have characteristic radiological features.

Suggestions for further research are that it is necessary to conduct more in-depth studies related to the relationship between CD4 and TCM results with radiological images of TB-HIV patients in different subjects and study designs so that the results obtained from similar studies are more perfect. Radiological examination 
should also clarify the type of image (infiltrates, fibronodular infiltrates, fibrosis, cavity), location, and the presence or absence of intrathoracic lymphadenopathy.

\section{Bibliography}

1. WHO. “Global Tuberculosis Report 2019”. World Health Organization (2019).

2. WHO. "Tuberculosis and HIV" (2020).

3. Glaziou P., et al. "Global Epidemiology of Tuberculosis". Cold Spring Harbor Perspectives in Medicine 5 (2015): 1-17.

4. Jendriella J., et al. "Gambaran Radiografi Toraks Pasien HIV Dengan Tuberkulosis Paru Berdasarkan Nilai CD4 Di Rumah Sakit Umum Arifin Achmad Provinsi Riau". Jurnal Ilmu Kedokteran 13.1 (2019): 36.

5. Dafitri I A and Medison I. "Laporan Kasus TB paru koinfeksi HIV/AIDS Case Report of Pulmonary TB with HIV/AIDS Coinfection". Jurnal Kedokteran Yarsi 28.2 (2020): 21-31.

6. Kristina Perwitasari D and Lolong D B. "DI KABUPATEN SORONG TAHUN 2014-2018 District Year 2014-2018”. (2020): 154-160.

7. Afriliyanti NI., et al. "Kemampuan Diagnostik Pemeriksaan Xpert dengan Acuan Kultur Media Cair pada Pasien HIV 2 MTB/RIF ®” 2.3 (2015).

8. Kisembo H N., et al. "Chest radiographic findings of pulmonary tuberculosis in severely immunocompromised patients with the human immunodeficiency virus". British Journal of Radiology 85.1014 (2012): 130-140.

9. Stanisavljev N P and Mitrovica S. "Radiological findings of tuberculosis in HIV positive patients". Ropean Society of Radiology (2013): 1-64.

10. Hanifa A L., et al. "Description of Early Diagnosed Hiv Patient Nutrition Status” (2019): 70-79.

11. Kementerian Kesehatan RI. "Pusat Data dan Informasi Kemenkes RI" (2018).
12. Sadewo S W., et al. "Gambaran Status Anemia pada Pasien Tuberkulosis Paru”. Jurnal Cerebellum 2 (2016): 590-600.

13. Baedowi A., et al. "Hubungan Jumlah Viral Load Dengan Kejadian TBC Pada Pasien HIV/AIDS”. 1.3 (2020): 233-240.

14. Wesnawa M A D P and Putra I N N. "Profil Pasien Koinfeksi TB - HIV”. Jurnal Respirologi Indonesia 36.3 (2016): 175-181.

15. Muna N and Cahyati W H. Higeia Journal of Public Health 3.2 (2019): 168-178.

16. Widiyanti M and Hutapea H. "Hubungan Jumlah Cluster of Differentiation 4 (CD4) dengan Infeksi Oportunistik Pada Pasien HIV/AIDS di Rumah Sakit Umum Daerah (RSUD) DOK II Jayapura". Jurnal Biologi Papua 7.1 (2015): 16-21.

17. Kurniawan E., et al. "Nilai Diagnostik Metode "Real Time" PCR GeneXpert pada TB Paru BTA Negatif”. Jurnal Kesehatan Andalas 5.3 (2016): 730-738.

18. Mboeik M LW., et al. "Performa Pemeriksaan Xpert MTB/RIF dengan Menggunakan Spesimen Bilasan Lambung dalam Mendiagnosis Tuberkulosis Paru pada Pasien HIV Tersangka Tuberkulosis Paru". Jurnal Penyakit Dalam Indonesia 5.1 (2018): 29.

19. Nugraha T., et al. "Evaluasi Metode GeneXpert MTB/RIF dengan Sampel Raw Sputum untuk Mendeteksi Tuberkulosis Paru. Evaluation of GeneXpert MTB/RIF Method Using Raw Sputum Samples for Detecting Pulmonary Tuberculosis" 2.1 (2018): 7-10.

20. Rosamarlina Murtiani F., et al. "Profil Pasien Suspek Koinfeksi TB pada HIV di Rumah Sakit”. (2015): 14-21.

21. Hidayat E Y., et al. "DUA DAN ENAM BULAN PENGOBATAN ANTI TUBERKULOSIS + ANTIRETROVIRAL (Studi Kasus di RSUP Dr. Kariadi dan BKPM Semarang)”. 1 (2015): 91-98.

22. Edwina I., et al. "Hubungan antara luas lesi pada foto toraks penderita tb paru dewasa yang memiliki riwayat diabetes melitus dengan indeks massa tubuh di rumah sakit hasan sadikin bandung. Correlation of Tuberculosis Lesion Size in Chest Radiographs of Diabetic Adult Patien". Jurnal Radiologi Indonesia 1 (2016): 138-144. 
23. Badie BM., et al. "Comparing radiological features of pulmonary tuberculosis with and without HIV infection". Journal of AIDS and Clinical Research 3.10 (2012): 3-5.

24. Agustya M., et al. "Profil Pasien Koinfeksi TB - HIV" 36.3 (2016): 175-181.

\section{Assets from publication with us}

- Prompt Acknowledgement after receiving the article

- Thorough Double blinded peer review

- Rapid Publication

- Issue of Publication Certificate

- High visibility of your Published work

Website: www.actascientific.com/

Submit Article: www.actascientific.com/submission.php

Email us: editor@actascientific.com

Contact us: +919182824667 